\title{
短波長放射中のガラス表面温度測定方法に関する実験的研究 EXPERIMENTAL STUDY ON MEASURING METHOD FOR GLASS SURFACE TEMPERATURE UNDER SHORTWAVE RADIANT ENVIRONMENTS
}

\author{
渡部真志*, 武田 仁** \\ Masashi WATANABE and Hitoshi TAKEDA
}

\begin{abstract}
This paper describes the measuring device for glass surface temperature under shortwave radiant environments.

The measuring method of proposing is as follows:

This method in which the cover glass (thickness $50 \mu \mathrm{m} \sim 75 \mu \mathrm{m}, 30 \mathrm{~mm}$ by $30 \mathrm{~mm}$ ) for use in electronics and microscopes, coated thinly and uniformly with a cyanoacrylate-based colorless and transparent glue, is gently bonded onto the glass specimen with bare thermocouple element with diameter of $25 \mu \mathrm{m}$ sandwiched in between.

We verify this measuring method by using radiation thermometer with a measurable wavelength range of approx. $8 \mu \mathrm{m}$ to $13 \mu \mathrm{m}$, under equal distribution of luminous intensity from background surface.
\end{abstract}

Keywords : glass surface temperature, shortwave radiation, cover glass, radiation thermometer ガラス表面温度，短波長放射，カバーガラス，放射温度計

1.はじめに

建築物を構成する休・壁・屋根等が比較的断熱性能を 高めやすく固定的であるのに対し，開口部（空）は断熱 性能を高めるこ之が相対的に難しい一方, 室内の良好な 環境の確保のために，また人間の精神的・社会的な求め に従い, 内・外部環境のかかわり合いを可変的に調節し 得る機能を伝統的に持つ唯一の部位であると言える。ま た，開口部 (空) と他の部位との違いを決定的にしてい るものは短波長放射について優れた透過特性を持つ板ガ ラスの存在であると思われ, 内・外を区画する面材とし て断熱性能上決して有利な材料とは言えないにもかかわ らず通常の空にほぼ不偏的に板ガラスが採用されている のは，採光（熱）や眺望という本質的にガラスが担って いる機能が, 人間が生活を営む一般的な空間に欠かすこ とのできない重要なものと認識されている現れであろ 亏。

開口部のこうした機能を生かし発展させながら，他の 部位に比べ熱的にも温冷感的にも弱点になりやすい宿命 をどう克服するかが, 開口部の大きな課題のひとつと考 えられる。空ガラスの表面温度は，こうした開口部にお ける熱流の把握や解析にとって有力な指標になり得ると
同時に，室内の熱的快適性や人体の温感の形成を検討す る場合にも欠かせないと言える。

以上のことから，本論文では短波長放射がある故に真 值が得にくいと考えられる開口部（空）のガラス表面温 度を，より明確に测定し得る方法の開発と，その測定値 を現実の地上における太陽放射の下で検証することを目 的とし, 短波長放射中のガラス表面温度測定方法として, どの程度の妥当性があるかについて論じることとする。

\section{2. 各種の表面温度測定方法とその誤差検討用基準温度} 建築環境工学においては，熱電対や測温抵抗体等の感 温素子を物体表面に接触固定させ伝導伝熱により感温素 子温度を真の物体表面温度に近似させてその表面温度を 得ようとする接触式表面温度测定方法は広く行われ, 测 定精度についても幾つかの研究事例が報告されている。

宮野・小林は如, 熱電対の種類, 貼付や接着の方法, 測定表面の材質や形状が測定誤差に及ぼす影響に関し て, 供試体材料内に埋め込まれた熱電対により得た定常 伝熱下の内部温度勾配より求めた温度を一応の真の表面 温度として検討を加えている。しかしながら，その基準 表面温度の扱い方を短波長放射の影響を受けている板ガ

\footnotetext{
本論文の一部は，1990 年の日本建築学会大会学術講演会に発表したものである。

* 東京理科大学理工学部建築学科 助手 Research Assoc., Dept. of Architecture, Faculty of Science and Tech-

** 東京理科大学理工学部建築学科 教授 $\cdot$ 工博 nology Science Univ. of Tokyo

Prof., Dept. of Architecture, Faculty of Science and Technology Science Univ. of Tokyo, Dr. Eng.
} 
ラスについて適用するには無理があるように思われる。 梅干野・塩月效1文4!らは，スリガラスや透明ガラスに 貼付材や接着剂により各種熱電対を接触固定させ，これ に白熱人工光源により放射を与え, 市販の走查式赤外線 放射温度計により得た放射温度画像を用いて，熱電対の 線径, 形状, 感温部の吸収率や貼付材の種類, 接着剤塗 布状態等の誤差要因が測定誤差に及ぼす影響について体 系的な検討を加え，一定の知見剂を得ているが，いず れの基準表面温度もその検証ができているとはいい難い 面があり, 誤差の検討のよりどころとなる基準值が暫定 的なものである感は否めない。

ところで, 赤外線放射温度計等によるいわば非接触式 表面温度測定方法は, 測定対象表面の温度場のかく乱が ない点で非常に優れているが，放射温度計が感度を有す る波長帯域についての対象表面の放射特性や，背景から の放射の影響と大気の吸収の把握という厄介な問題を解 決する必要がある。特に常温近辺の物体を対象とする場 合, 波長 8 - 14 $\mu \mathrm{m}$ 前後の検出範囲が SN 比上最も有利 となるが，この波長域でガラスを測定対象とする場合， 背景からの放射の反射成分の影響が無視できない問題亡 なる。

梅干野ら文6) は，ガラスによる放射の反射がほとんど ない波長帯域 $(6.5$ - 8.6 $\mu \mathrm{m})$ に感度波長带を持つ放射 カメラを試作し，そのガラス表面温度測定結果に周囲の 高温物体からの放射の影響がほとんど出ないことを明ら かにしている。しかし，この方法により常温域のガラス 表面温度の絶対值を高い精度で定量化することは, 測定 波長帯域を皎り込んだために常温物体から射出されるも ともと大きいとは言えない放射エネルギーの限られた一 部しか利用しておらず, SN 比上難しい面があるのでは ないかと予想される。

また筆者ら文7ー吝11も熱平衡式によるガラス温度推定 方法文12)，独自の考案のものも含む接触式および非接触 式測定方法等, 計 4 つの测定方法を用意し, 現実の太陽 放射の存在する屋外実験を中心に 1 つのガラス供試体に ついて同時にこれらの測定を実施し，その各測温の比較 により，未知の真のガラスの温度を直線の交点を求める ように探りだそうとしてきたが，表面からの放射を検出

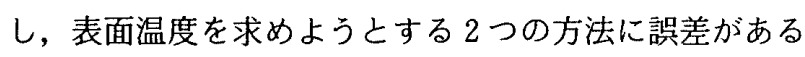
程度入る余地を排除しきれず, 真值を求めるための直線 を一定の幅を持つ帯と見なすべきであることが明らかに なりつつあり, 基準温度がこの帯の幅の中のよ゙の辺りに あるかは特定できないと言える。

以上の検討に上り，基準温度をより明確にするための 測定方法の開発を非接触式測定方法の範囲内で行った り，それの絶対性を根拠とする形で他の方法との比較か ら基準温度としての妥当性を検証することには現時点で はなかなかに越え難い難しさがあると考え，本研究では
基本として接触式の範囲内で測定方法の開発を行い, 接 触式の大きな欠点と言える測温体の接触による测定対象 表面温度場のかく乱を極力抑える方法を考究することと した。

\section{3. 本論文のガラス表面温度測定方法}

接触式表面温度測定方法の場合, 測定対象表面に熱的 に異なる特性を持つ測温体表面を形成している限り本質 的な限界があり，またそのことにより検証の手掛かりる つかみにくくなっていると思われる。むしろ, 測定対潒 表面に測温体を形成した後もその表面が本来の唛面と事 実上変わらないと考えられる方法を追求する方が測定精 度上も有利であり, 検証を進めるうえでも同一表面の相 対的な温度差の有 - 無を非接触で検出し得る放射温度計 の長所を活用でき，活路が開けると考えられる。

そこで本研究では，原理的に測温体装着後も装着前上 表面の短・長波長放射に対する特性がほとんど变化し子 いと考えられる公称厚 $50 \sim 75 \mu \mathrm{m}$, 大きさ $30 \mathrm{~mm} \times 30$ $\mathrm{mm}$ の透明ガラスシート (以下, カバーガラスと称する) を用い, 極細線径の熱電対を測定対象表面に被覆接着す ることとした。従来まで, 通常の建材の表面温度測定に 用いられることが多かったと思われる一般的な合成樹脂 製ベースの粘着テープは, そのベース厚が約 $50 \mu \mathrm{m}$, 接 着層厚が約 $25 \mu \mathrm{m}$ 前後济であり, 本研究のカバーガラ スはこれとほぼ同じ水準の厚さと言え, 被覆材乞して用 いた大きさも $30 \mathrm{~mm}$ 角と, その公称厚の 600 倍から 400 倍の平面的広がりを持っているため, 対流熱伝達量 を違ったものにするほど表面近傍での気流をかく乱する ことは無いと考えられる。

感温素子には基本として $\mathrm{K}$ 型神2)の裸熱電対点用いる こととし，それ自体の短波長放射特性のガラスにの違い による影響を極力抑えることを意図して，その溸線径は

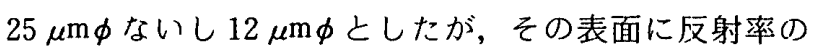
高い異種の金属膜を形成することは熱起電力への影響㝋 懸念して行っていない（以下，これを無処理と称する)。 また，比較のために素線径 $25 \mu \mathrm{m} \phi$ の 型無処理熱電対 も用いた。素線径を $25 \mu \mathrm{m} \phi$ 以下とすることにより，力 バーガラスで被覆される熱電対の各構成金属線の長さ は, 感温接点を中心として各々素線径の 600 倍前後以上 となる。

この熱電対を測定対象表面にカバーガラスで被覆接着 する際に用いる無色透明接着剂(主3)はシアノアクリレ一 卜系の低粘性型のものとした。この接着剤は,その 100 \%成分であるシアノアクリレートモノマーが材料表面 や空気中の水酸基 : $\mathrm{OH}^{-}$(主に水蒸気中の) に上りア二 オン重合反応を起こし，シアノアクリレートポリマーに 変化することにより接着力の発現が得られる夕イプのる ので, ガラスとカバーガラスの間でも比較的短時間に硬 
化し気泡も入りにくい。また，接着初期の粘性が他の接 着剤に比べ適度に低く，貼付したカバーガラスを軽くガ ラスに押し当てる操作により余分な接着剂を周囲に押し 出すことが可能で，これにより接着層の厚さを熱電対の 素線径程度に管理することが比較的容易である。さらに 万一接着層内に微小な気泡が入った場合も，同様の操作 によりこれをカバーガラスの外へ押し出せる場合が多 い。

この接着剤が硬化した後のシアノアクリレートポリ マーという樹脂はアクリル酸のアルキル基がエチルと簡 素であるため, アクリル板と通称されているアクリル酸 メタクリレート（メタアクリレートポリマー）とその原 子構造の主要骨格が近く, 種々の物性は互いに非常に似 ていると言える。アクリル板（厚 $3 \mathrm{~mm}$ ) は，地上にお ける太陽放射のエネルギー強度が大きい波長域において 透明板ガラスを上回る透過特性文13)を示しており，本報 で用いたシアノアクリレート系接着娮の硬化後の透過特 性もこれに近いものと考えられる。このような短波長域 における特性は長波長放射を透過しない透明板ガラスと カバーガラスの間に位置する薄い中間層としては問題の 少ないものと考えられた。

\section{4. 検証実験方法}

本論文のガラス表面温度測定方法により得られた測温 が, 本来の測定対象ガラス表面温度と必要十分な水準で 一致していることが検証できれば，前章 3.で提案した 方法は, その水準の範囲内でガラス表面の基準温度を測 定し得る方法であると言い得よう。

本研究ではこの検証をカバーガラスで測定対象表面に 被覆接着した極細線径の熱電対感温接点の温度とカバー ガラスの空気側の表面温度とを, カバーガラスの熱伝導 率やその薄さから考えて実用上等しいと見なし，にこの 検討は, 後述 6. 章) このカバーガラス表面温とその周 囲の測定対象板ガラス表面温との間に温度差が存在する かを, 高分解能の走查式赤外線放射温度計による双方の 表面の放射温度画像示度の相対比較で検証することとし た。

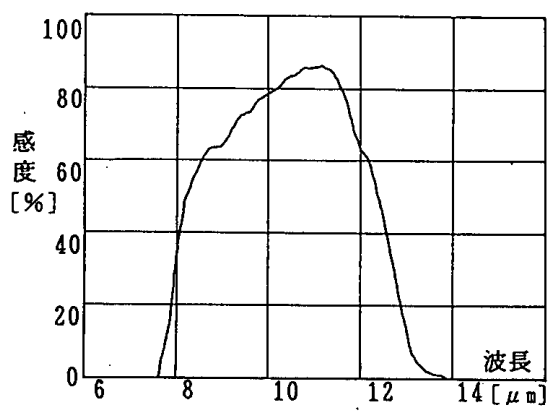

図一1 本論の放射温度計の総合感度特性
放射温度計は測定対象表面温度場のかく乱が無いた め, 大気の吸収之背景の放射環境が同一の状況下で，隣 接する同一の材料表面の相対的な温度比較を行うには大 変適した機能を有していると言え，面的な温度分布を検 出し得る走查式放射温度計は，その走查形式により大き く2つのタイプに分かれる。1つは，一画面を例えば上・ 中・下と 3 つに分割し, 三器の検知器で同時に走查する ことにより一画面の走査時間の短縮を组ったもので，も う一方は, 一器の検知器により一画面を統一して走查す るタイプで, 画面全域を均一な特性で走査でき, 表面温 度の時系列変化が比較的遅い静止した物体の各所の表面 温度の相対比較などの場合に厳密性を確保しゃすいと言 えるものであり，本研究では後者のタイプを採用した。

この走查式放射温度計に搭載されている検知器は M. C. T. ( Hg-Cd-Te : 液体窒素冷却型) で常温域の物 体表面から射出される放射の放射発散輝度が最も高くな る波長域に対し，その検知度も最も高くなる性質の量子 型検知器で，常温域の物体表面から射出される放射の検 出において高い SN 比を確保するのに非常に有利と言え る。本研究では，同一メーカー製の機種（世代）の異な るこのタイプの放射温度計を 2 台用いているが，これら の放射温度計検出部を構成する検知器や光学系の本質的 な機能や構造は同一のもので, 後世代の方は検出した表 面温度情報の演算処理機能が前世代の機種に対し向上し ているだけである。

この 2 台の放射温度計検出部の光学系も含めた総合感 度特性 (メーカー公表)を図一1に示す。これらの放射 温度計が感度を有する波長域は, 約 8 13 $\mu \mathrm{m}$ (ピーク に対する半值幅望4)による表示) である。通常の測定モー ドにおいて $30^{\circ} \mathrm{C}$ の黒体を走査する場合, 仕様書で公称 されている相対的な表面温度差検知能力（最小検知温度 美）は 2 台とも $0.1^{\circ} \mathrm{C}$ となっているが，実際の検証実 験の際には, 日射量や風速が安定し表面温度の時系列変 化がほとんど無いと思われる状況下において，4回分な いし 16 回分（後世代機種のみ）の走査情報を各々加算 平均することにより SN 比を向上させる SN 比改善と メーカーが称する測定処理モードにおいて放射温度画像

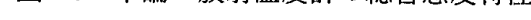

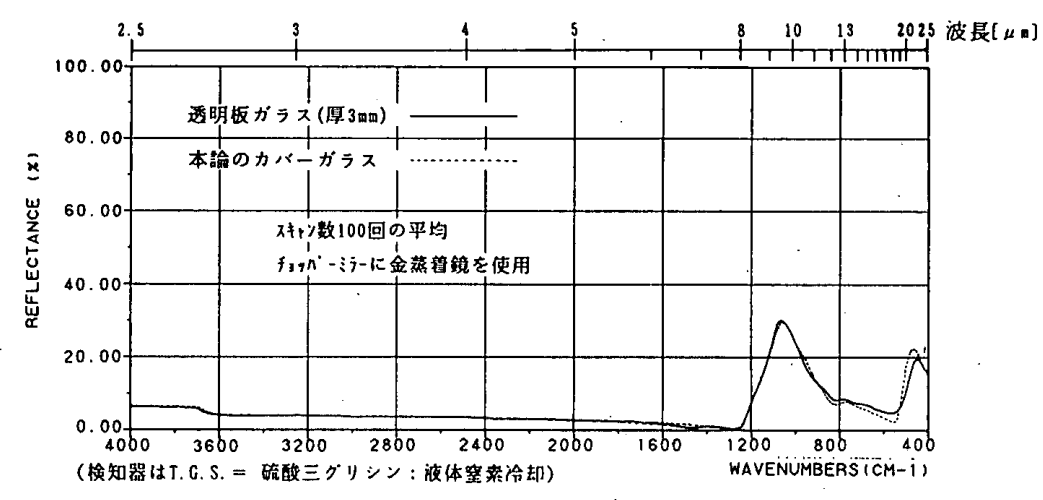

図一2 透明板ガラス（厚 $3 \mathrm{~mm}$ ) とカバーガラスの分光反射特性 
の収録を行った。この場合の最小検知温度差はかなり向 上し, 常温域を中心とする温度測定範囲について, 4 回 分の走查情報を加算平均する千ードで $0.05^{\circ} \mathrm{C}$, 同 16 回 分の走査情報を加算平均するモードで $0.025^{\circ} \mathrm{C}$ の水準 が仕様として公称されている。

隣接するカバーガラス表面と周囲の測定対象ガラス表 面との温度が一致しているかを，この走査式放射温度計 で検証しようとする場合, 非常に重要になってくるのは, 使用した放射温度計の測定波長帯域における双方の表面 の放射特性の一致の程度であると考えられる。そこで本 研究では, カバーガラスを装着していない測定対象その ものである建材用透明板ガラス (厚 $3 \mathrm{~mm}$ ) 表面と, こ の透明板ガラスに前章 3. で述べた方法によりカバーガ ラスを被覆接着した場合のカバーガラス表面との赤外域 分光反射特性をフーリ工変換型の赤外分光光度計にて測 定した。その結果を図一2に示す。波長が約 $4.5 \mu \mathrm{m}$ 前 後より長い領域では双方の供試体とも透過が無いため, 反射率特性の一致は放射率特性の一致を意味する。この 図から明らかなように，放射温度計が感度を有する約 8

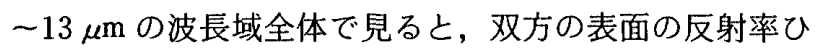
いては放射率は実質的に同一と見なせる。

ただし，放射温度計の測定波長域とガラスの反射が高 くなる波長域がほぼ重複するため, 周囲からの放射がガ ラス表面において反射されたものも放射温度計にて検出 されることになり，放射温度計の放射温度画像により， カバーガラス表面から射出される放射エネルギーと本来 のガラス表面から射出される放射エネルギーとが同一で あることを検証するためには，ガラス表面で反射して放 射温度計の視野内に入る背景からの放射を放射発散輝度 面分布の均一なものにする必要がある。

そのため, 検証実験は図一3に示す南向きの開口部(厚 $3 \mathrm{~mm}$ 透明板ガラス) を持つ $\mathrm{RC}$ 造打ち放しの小室を用 い, 開口部の空ガラスに装着した本論文の測温体や比較 のために用意した各種測温体（後述）およびその周囲の ガラス表面からの放射をおおむね図に示すような状況で 検出することとした。放射温度計の視野に入る背景面に は, 急激な温度変動が起こりにくく, 夜間の蓄冷により 昼間に日射を受けているガラスに比べ相対的に低温と予 想される RC 造の壁体を用いることとし, 背景面の範 囲はガラス表面上において測温体の設置可能性のある範 囲を放射温度計の視野に収め，その中に写り込んでいる 背景の RC 壁上の範囲が比較的温度分布幅の小さそう な壁の中央寄りの部分になるように，なおかつガラス表 面の法線に対し放射温度計の視野中心線がなす角が極端 に大きくならないように，各要素のバランスをとりなが ら放射温度計の位置を変更・調整しつつ決定した。

この背景面には素線径 $100 \mu \mathrm{m} \phi$ の 型無処理熱電対 を接着剤で直付けし，その上から表面の均一な放射特性
と周囲からの放射の 不用意な反射を極力 抑えることを意図し て, 全波長域につい てその放射（吸収） 率が 0.98 以上と称 されているパーンン ズ社製オプティカル ブラックを吹き付け 塗装した。背景面の 熱電対感温接点の配 置と前述の塗装範井 は，図一4に示すよ うに放射温度計視野 内背景面よりかなり 大きく取り，コンク リートと塗装面との 放射率の違いによる 放射熱収支の違いが 視野内背景面内の温 度分布をかく乱する

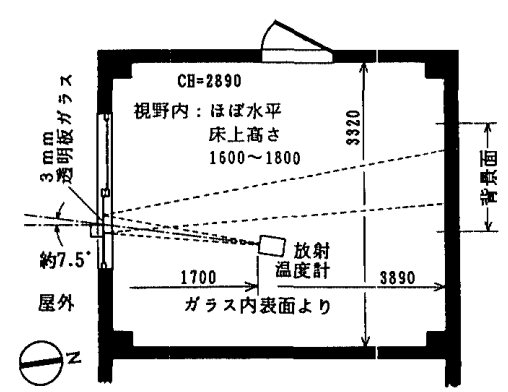

図一3 窒内側検証実験状況概要

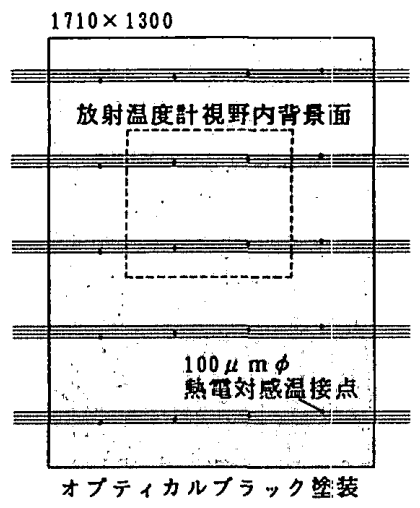

图一4 背景面概要
懸念を少なくした。放射温度計で視野内背景面を直接走 查した放射温度画像（最小検知温度差 $0.05^{\circ} \mathrm{C}$ 没定）に はほとんど温度むらが認められず, 後述のデータロガー 等による視野内背景面の熱電対測温もロガーの温度測定 分解能 $0.1^{\circ} \mathrm{C}$ の水準でほとんどの場合互いに一致して おり，まれに差がついたとしても $0.1 \sim 0.2^{\circ} \mathrm{C}$ の範囲に あった。検証実験の放射温度画像の収録は,これらの温 度が $0.1^{\circ} \mathrm{C}$ の水準で一致している時に行った。

以上のことより, 検証実験中の放射温度計の視野内に 入射する背景からの放射の放射発散輝度面分布は実用上 均一なものにできたと考える。また測定対象ガラス表面 と放射温度計検出部ウインドウ面との距離は最大で約 $1700 \mathrm{~mm}$ であり, 特別な加湿なども行っていない通常 の室内であるため空気による放射の吸収も極めて小さく 視野内の伝搬経路上の吸収の差も無いと考えられる。

本論文で提案したガラス表面温度用測温体を始め, 比 較のために用意した後述の測温体等に用いた熱電対は, 前述の背景面用のものも含め, 文献 14）で行った方法 に準じてその校正を行い, $0^{\circ} \mathrm{C}, 10^{\circ} \mathrm{C}, 20^{\circ} \mathrm{C}, 30^{\circ} \mathrm{C}$, $40^{\circ} \mathrm{C}$ の校正温度設定全体にわたり測温（後述のデータ ロガー等による) が一致するもののみを感温素子として 採用した。

温度測定については, 電王測定分解能 $1 \dot{\mu} \mathrm{V}$ のデータ ロガーを用い零点補償は電子式零接点装置を用いた。こ の装置の零点の精度はメーカーによると $0.00^{\circ} \mathrm{C} \rightarrow+$ $0.05^{\circ} \mathrm{C}$ の範囲にあり, 周囲温度と熱電対の種類や本数 によって零点精度が異なり，詳細は特性線図参照と称さ 
れているが，零点槽の中に挿入する零接点用プローブの 数が増えてくれば, プローブ用熱電対線を通して伝導で 外乱が槽内に及び，零点の精度が低下することは明らか であるため，メーカー製零接点用プローブ（素線径 200 $\mu \mathrm{m} \phi)$ を用いず，ガラス表面温度用感温素子に用いた 前述の熱電対と同一メーカー製の素線径 $75 \mu \mathrm{m} \phi$ テフロ ン薄膜被覆熱電対を電磁誘導誤差を嫌ってツイスト処理 し自作の零接点用プローブとした。本研究で使用した熱 電対は $\mathrm{K}$ 型が主流であるが, 零接点装置メーカー公表の 零点精度算出用特性線図によると, $\mathrm{K}$ 型メ一カ一製プ ローブ 24 対が負荷として零点槽内に挿入され，装置の 周囲温度が $25^{\circ} \mathrm{C}$ の時には, その零点精度は $0.01^{\circ} \mathrm{C}$ と 読み取れる。本研究の自作零接点用プローブの場合, 細 線径化した分, 外乱が槽内に到達しにくく，検証実験時 挿入数も最大で 15 対としたため, 槽内の零点精度は前 述の読み取り値よりは向上し，安定性も増したものに なっていると考えられる。

測温体に使用した熱電対とデータロガー端子板および 零接点用プローブとの間を結ぶ信号線には補償導線など を用いず, 感温接点を構成している熱電対素線と同素材 (同一メーカー製) の素線径 $250 \mu \mathrm{m} \phi$ のテフロン被覆 熱電対線を用い，その総延長を熱電対校正時も含めて各 感温接点ともほぼ $4 \mathrm{~m}$ 程度とし，いたずらに熱電対自 体の電気抵抗が増えることを抑え，同型熱電対同士の間 の電気抵抗に大きな違いが出ないようでき得る限りの配 慮をした。

実際の検証実験に際しては，日射量と板ガラス近傍の 外気温, 外気風速, 室内空気温, 室内風速を併せて測定 した。日射量は熱流素子型の精密全天日射計を用い; そ の受感面を板ガラス面と平行にガラス面から $20 \mathrm{~cm}$ 程 度離して設置した。外気温, 室内空気温は文献 14)で 報告した空気温度計を用いた。内・外風速は熱線風速計 を用い，外気側は無指向性プローブを，室内側は指向性 プローブを空近傍の自然気流の方向を考えて昼間は下向 き，夜間は上向きとした。空気温度計の空気吸引口と熱 線風速計のプローブは, 外気側・室内側共，ガラス面よ り約 $25 \mathrm{~cm}$ 離した。外気側各側定器は, それ自体の影 が実験中の板ガラス測定対象範囲に入らないような配置 とした。

放射温度計に入力する板ガラス表面の放射率には，放 射温度計の測定波長域について，その総合感度特性の重 みを掛けた値（0.85）を用いることを原則としたが，後 述の無色透明テープ被覆等の测温体がある場合は適宜 0.90 1.00 の值を用いた。本論文の検証実験の趣旨が, 測温体として装着されたカバーガラス表面とその周囲の 板ガラス表面との相対的な温度差の有・無の検出にある ため，一画面の放射温度画像中に問題となる双方の表面 が存在すれば，余り低い放射率を入力しない限り，これ
らの表面温度の相対比較には問題はないと考えられる。

\section{5. 検証害験内容とその結果}

写真一1 は, 厚 $3 \mathrm{~mm}$ の透明板ガラスの室内側表面に 熱電対を挟まずにカバーガラスのみをシアノアクリレー 卜系接着㓮を用い装着したものを夜間に放射温度画像化 したものである。この時の板ガラスおよび放射温度計の 配置と背景面の概要については, 前章 4. の図一 3 と図 一4で示してあるとおり（以下，写真一11 まではほぼこ の実験状況）である。放射温度画像上の温度分布グラフ 一目盛りは画像示度 $0.1^{\circ} \mathrm{C}$ に設定してあり, 縌・横の 温度分布グラフは各々縦・横のカーソル線上の放射温度 画像示度を示し, 縦グラフの左端と横グラフの下端の目 盛線がカラーバーの下端の放射温度画像示度(この場合, $\left.13.8^{\circ} \mathrm{C}\right)$ に, 縦グラフ右端と横グラフ上端の目盛線が カラーバーの上端の放射温度画像示度 (同 $14.6^{\circ} \mathrm{C}$ ) に 対応している(以下，すべて同じ）。また，この時の最 小検知温度差は $0.05^{\circ} \mathrm{C}$ の水準（以下, 写真一7 までの 放射温度画像は同水準）にある。

写真一1では，垂れ落ちたシアノアクリレート系接着 剤の表面が周囲のガラス表面よりわずかに低い放射温度 画像示度として示されているだけで，カバーガラスとそ の周囲のガラスとの間に差は認められない。さらに板ガ ラス全体についてわずかに存在する上下方向の画像示度 勾配が，対応する高さごとのカバーガラス表面上でも一 致して認められる。また, 画面右寄りの淡紅色の部分は, カバーガラス位置出し用のマーカとして, 板ガラスの室 内側表面に貼付したアルミテープの放射温度画像であ る。

次に, このアルミテープマーカの右斜め下の板ガラス 表面に, 素線径 $25 \mu \mathrm{m} \phi$ の 型無処理熱電対を小さく成 形されたビニールテープで水平に仮止めし，その感温接 点を中心之する熱電対素線部分を前章 3. で述べた方法 で，カバーガラスにより被覆接着した。写真一 2 は，こ の部分を中心とする板ガラス表面を日射量（板ガラス外 表面入射全日射量, 以下同じ）約. $404 \mathrm{kcal} / \mathrm{m}^{2} \mathrm{~h}$ の昼間 に前述之同様の方法により得た放射温度画像である。接 着剤表面の部分は, 周囲のガラスに対し画像示度上で約 $0.4 \sim 0.5^{\circ} \mathrm{C}$ 高めになっているのに対し，カバーガラス 表面の放射温度画像は，熱電対の有・無にかかわらず周 囲のガラス表面と同一状態であることが認められる。

写真一 3 は, 図一 3 の透明板ガラスを $8 \mathrm{~mm}$ 厚のもの に替え，その室内側表面に $25 \mu \mathrm{m} \phi \mathrm{K}$ 型無処理熱電対を カバーガラスで被覆接着したもので，左・右に延びる熱 電対素線を ABS 樹脂系無色透明接着剛で直付けし, 前 述の方法により日射量約 $508 \mathrm{kcal} / \mathrm{m}^{2} \mathrm{~h}$ の下で放射温度 画像化したものである。この測温体の装着および素線の 直付けについては敢えて筆者が行わず，この作業の経験 
を持たない本学建築学科学生 (22才)にその方法を解 説したうえで実施してもらった。この写真一3の放射温 度画像上で， Bゾーンはカバーガラス表面の画像示度の

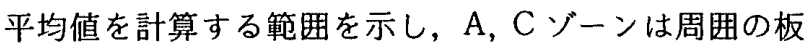
ガラス表面の計算範囲を示している。この各ゾーンの平 均画像示度が画面左側にゾーンごとに AVEと表示され ているもので, MIN, MAX は画像示度の最小と最大の 值が表示される。これらによると，カバーガラス表面と その周囲の測定対象ガラス表面との放射温度画像示度の 前述三指標は完全に一致し，双方の間にこの放射温度計 で識別し得る以上の表面温度差が無いことが分かる。

一方，ABS 系無色透明接着剤により直付された熱電 対素線部分の放射温度画像示度は，力バーガラス上のも のに比べ約 $0.3^{\circ} \mathrm{C} \sim 1.0^{\circ} \mathrm{C}$ 近くも高く, その分布にもむ らがある。この画像示度のむらは主に接着剤厚のむらに よるものと考えられる。またカバーガラス内左手にある 粒状の高示度部分は熱電対直付の際に付着した ABS 系 接着㨈の微小な滴であり，その下方の流れ出すような高 示度部分はカバーガラスを被覆接着する際に押し出され たシアノアクリレート系接着剮である。

次の検証実験では空ガラスをひき続き厚 $8 \mathrm{~mm}$ の透明 板ガラスとし, カバーガラス被覆熱電対 $(25 \mu \mathrm{m} \phi \mathrm{K}$ 型 無処理) を前述同様, 作業未経験の本学学生に室内側に $2 つ$, 室外側に $1 つ$ ，ぼ同じ位置に装着してももらった。 カバーガラスから外へ延びる熱電対素線は, ABS 系無 色透明接着剤により板ガラス表面に直付しているが，室 内側の一方の側温体の熱電対素線を直付する際には，接 着剤をできる限り少量にするよう心掛けてもらい, その 一部が最初に装着された室内側のカバーガラスに少し掛 かるようにしてもらった。この板ガラス上の各測温体を 室内側から通常の一眼レフカメラで撮影したものが写真 -4である。

これを日射量約 $345 \mathrm{kcal} / \mathrm{m}^{2} \mathrm{~h}$ の下で放射温度画像と したものが写真一5である。この場合でも $2 つ$ 5 ガー ガラス表面とその周囲の透明板ガラス表面との間に放射 温度画像示度上の差異は認められず，対応する各ゾーン の画像示度の三指標もすべて同一である。熱電対直付部 分の画像示度分布はカバーガラス上に対し最大で約 0.8 ${ }^{\circ} \mathrm{C}$ 以上高く, 上帠幅にもむらがある。一方, 外気側の

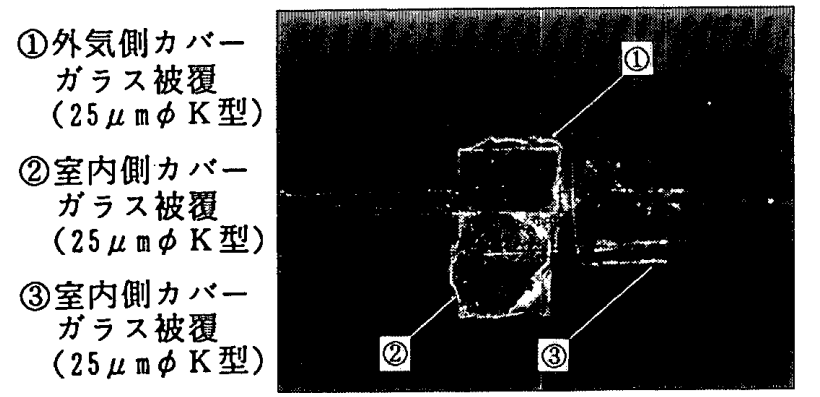

写真一4 内・外表面の本論文測温体の目視外観
本論文測温体による室内側表面温度場かく乱の兆候は認 められず，カバーガラス上に直付された熱電対の影響も 感温接点真上のカバーガラスまでは波及していない。こ の時の室内側のカバーガラス被覆熱電対測温は 2 つ共 28. $3^{\circ} \mathrm{C}$ であった。

写真一 6 と写真一 7 は, 表面温度情報としては同一の 一画像である。板ガラス表面上の測温体は，写真一5の 透明板ガラス室内側の 2 つのカバーガラス被覆熱電対を 挟み，その上・下に，上から順にベース材がアセテート フィルム製の無色透明粘着テープ（通称：メンディンダ テープ), 同セロファンフィルム製の無色透明粘着テープ (通称：セロハンテープ) と, スチロール系, シア， アクリレート系の無色透明接着剈で筆者が貼付抢るいは 直付した熱電対（すべて $25 \mu \mathrm{m} \phi \mathrm{K}$ 型無処理）である。 透明テープの左・右に延びる熱電対素線は, 画面外の部 分で小さく成形されたビニールテープで引張力を掛けて 仮止めしてあるだけ（以下，後述の測温体からの素線は 同処置)である。

両画面で，一番上の透明テープの左端より左側の部分 は，板ガラスから法線方向距離で $135 \mathrm{~cm}$ 程度のところ に設置した幅 $15 \mathrm{~cm}$ の遮蔽板により直達日射が遮蔽さ れており，画面右側の全日射量約 $272 \mathrm{kcal} / \mathrm{m}^{2} h_{\text {が }}$ 入射 する部分との温度差に起因する伝導伝熱により板ガラス に水平方向の温度勾配が生じている。この時, カバーガ ラスが装着されている位置と同じ温度分布になると思わ れる周囲の板ガラス表面と，当概カバーガラス敖面との 放射温度画像示度を調べてみたが，左・右のカバーガラ ス共, 対応する各ゾーンと画像示度の平均值, 最小值, 最大値がすべて一致していた。なお，左・右のカバーガ ラス被覆熱電対测温（左 $19.4^{\circ} \mathrm{C}$, 右 $19.6^{\circ} \mathrm{C}$ ) の差は, 各々の放射温度画像示度の差と等しいものであった。

写真一8では空ガラスを厚さ $3 \mathrm{~mm}$ の透明板ガラスに 尽した。画面の左端の Aゾーンには, $12 \mu \mathrm{m} \phi \mathrm{K}$ 型無姏 理熱電対がカバーガラスにより被覆接着されており，こ のすぐ上の高示度部分は，カバーガラスを接着する際に 余分な量としてカバーガラスの外緣部に押し出されたシ アノアクリレート系接着剤である。画面反対側不端の $\mathrm{E}$ ゾーンは, $25 \mu \mathrm{m} \phi \mathrm{T}$ 型無処理熱電対を被覆接着してい るカバーガラスである。この時の日射量は約 433 $\mathrm{kcal} / \mathrm{m}^{2} \mathrm{~h}$, 放射温度計の最小検知温度差は $0.025^{\circ} \mathrm{C} の$ 水準（以下，写真一 13 までの放射温度画像はこれと同 水準) の設定である。この場合でも，カバーガラス上の 放射温度画像は周囲の板ガラス上のものと全く夙様であ り, $\mathrm{A}, \mathrm{B}, \mathrm{E}$ 各ゾーンの画像示度の平均, 最小, 最大 值表示（各ゾーンの表示は上からこの順）も互いに同一 となっている。この時の双方のカバーガラス被嗄熱電対 測温は共に $18.5^{\circ} \mathrm{C}$ であった。

画面中央の 4 箇所の高示度部分は, より左寄りの位置 
から順にセロファンフィルム (Dゾーン), アセトテー トフィルム (Cゾーン) テープ貼付の $25 \mu \mathrm{m} \phi \mathrm{K}$ 型無処 理熱電対と, アセテートフィルム, セロファンフィルム テープ貼付の $25 \mu \mathrm{m} \phi \mathrm{T}$ 型無処理熱電対である。これら 各透明粘着テープの見附サイズはすべて $12 \mathrm{~mm} \times 30 \mathrm{~mm}$ であるが，この大きさに相当するのは各テープの画像の 淡紅色部程度であり, 各テープ周囲のガラス表面温度場 がかく乱されている様態が良く分かる。なおこの時のセ ロファンフィルム被覆熱電対の测温は $\mathrm{K}, \mathrm{T}$ 型共 18. $6{ }^{\circ} \mathrm{C}$, アセテートフィルム被覆の場合は同 $18.8^{\circ} \mathrm{C} て ゙$ あった。

写真一 9 は，写真一 8 と全く同じ板ガラス表面を，放 射温度計のズーム機能を働かせ，その走查範囲を広め， 日射量約 $623 \mathrm{kcal} / \mathrm{m}^{2} \mathrm{~h}$ の下で放射温度画像化したもの である。測温体周辺の比較的応い範囲にわたり大きな温 度むらがないことが伺え，測温体周囲の様態もおおむね 写真一 8 と同様である。画面の上・下縁の高示度部分は 熱電対を仮配置している円形のビニールテープで, 周囲 のガラス表面の温度場かく乱の様態が分かる。また画面 左側の大きな高示度部分は放射温度計からの放射の反射 によるものである。この状況下のカバーガラス被覆によ る $\mathrm{K}$ 型 $12 \mu \mathrm{m} \phi, \quad \mathrm{T}$ 型 $25 \mu \mathrm{m} \phi$ の熱電対測温は共に $15.5^{\circ} \mathrm{C}$, セロファンフィルム被覆 $25 \mu \mathrm{m} \phi$ 熱電対測温は $\mathrm{K}$ 型で $15.6^{\circ} \mathrm{C}, \mathrm{T}$ 型で $15.7^{\circ} \mathrm{C}$ であり，アセテートフィ ルム被覆 $25 \mu \mathrm{m} \phi$ 熱電対測温は $\mathrm{K}$ 型, $\mathrm{T}$ 型とも $15.9^{\circ} \mathrm{C}$ であった。

写真一 10 と写真一 11 も，板ガラスおよびその室内側 表面の測温体の種類と配置は写真一 8,9 と全く同一で, 写真一 10 の日射量が約 $559 \mathrm{kcal} / \mathrm{m}^{2} \mathrm{~h}$ ，写真一 11 では約 $582 \mathrm{kcal} / \mathrm{m}^{2} \mathrm{~h}$ である。縦・横のカーソル線上の放射温 度画像示度分布を見ると, カバーガラスとその周囲の板 ガラスが同じ画像示度であるのに対し，透明テープとそ の近傍のガラス部や接着剤の折出箇所の画像示度がその 周囲の板ガラスに対して高くなっている様態が分かる。 両方の画面上に設定した各ゾーンの画像示度三指標を見 ても，カバーガラスとその周囲の板ガラスには全く差が 認められないのに対し，アセテートフィルムは板ガラス より平均画像示度で $0.6^{\circ} \mathrm{C}$ 高く, セロファンフィルム は同 $0.4^{\circ} \mathrm{C}$ 高い。実際の各測温体の熱電対測温は, 写 真一 10,11 共, カバーガラス被覆熱電対 $(12 \mu \mathrm{m} \phi \mathrm{K}$ 型, $25 \mu \mathrm{m} \phi \mathrm{T}$ 型共) が $11.3^{\circ} \mathrm{C}$ に対し，アセテートフィルム 被覆 (25 $\mu \mathrm{m} \phi \mathrm{K}$ 型, $\mathrm{T}$ 型共) が $11.6^{\circ} \mathrm{C}$ と $0.3^{\circ} \mathrm{C}$ 高く, セロファンフィルム被覆（25 $\mu \mathrm{m} \phi \mathrm{K}$ 型， $\mathrm{T}$ 型共）が $11.4^{\circ} \mathrm{C}$ と $0.1^{\circ} \mathrm{C}$ 高いにとよ゙まる。この時の背景面熱電 対測温は, 写真- 10,11 共 $7.8^{\circ} \mathrm{C}$ であった。

写真一 12 は写真一8 11 の板ガラス (3 mm 厚) の外 表面側にカバーガラス被覆熱電対 ( $25 \mu \mathrm{m} \phi \mathrm{K}$ 型無処理) を一つだけ装着し，図一5に示す実験状況で日射量約

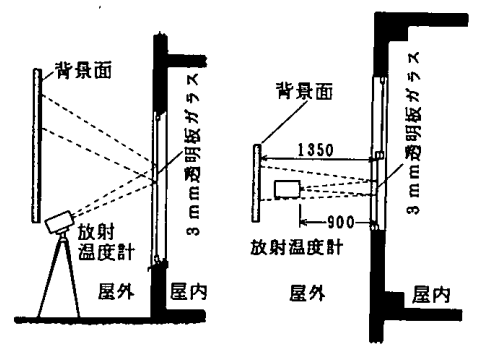

図一5 外気側検証奏験状況

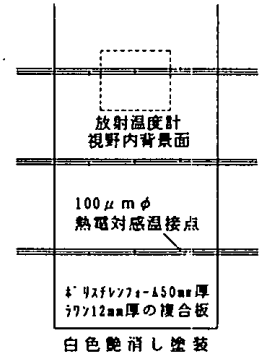

図一6 外気側背景面
$380 \mathrm{kcal} / \mathrm{m}^{2} \mathrm{~h}$ の下, 外気側より放射温度画像化したも のである。外表面側に他の測温体の装着は一切無い。放 射温度計の視野内に入る背景からの放射の放射発散輝度 面分布を均一なものとするための背景面として図一6に 示すものを作製した。実験中の視野内背景面の熟電対測 温とその周囲 5 点の熱電対測温との差は $0.2^{\circ} \mathrm{C}$ 以内で あり, 放射温度計による視野内背景面の画像示度分布も $0.2^{\circ} \mathrm{C}$ 以内であった。

写真一12 の画像中でも, 装着したカバーガラス（B ゾーン) と本来の板ガラス (Aゾーン) の画像示度の 平均值, 最小值, 最大值はすべて一致しており, 外気側 表面においても熱電対を被覆接着しているカバーガラス 表面とその周囲の板ガラス表面との間には放射温度画像 上の差異が認められなかったと言える。また，カバーガ ラス外緣に押し出されたシアノアクリレート係接着郕 は，周囲の板ガラスより相対的に低い画像示度として表 示された。この時の周囲の板ガラスや外表面カバーガラ スのゾーン別の画像示度平均值は $10.7^{\circ} \mathrm{C}$, カバーガラ 又被覆熱電対測温は $15.0^{\circ} \mathrm{C}$, 視野内背景面の魰電対測 温は $18.1^{\circ} \mathrm{C}$ であった。

一方, この画像で C, D ゾーンの位置の裏側（室内側） は, 各々写真一 10 のC (アセテートフィルム被覆), D ( ロファンフィルム被覆) ゾーンであり, 室内側に貼付さ れたアセテートフィルムの影響が外表面の温度場にも及 んでいることが分かる。その画像示度平均値の上昇は周 囲の板ガラス表面（Aゾーン）と比べて $0.3^{\circ} \mathrm{C}$ である。 室内側にセロファンフィルムが貼付されている外表面側 の Dゾーンでは画像示度平均值は周囲の板ガラスと同じ であるが，最小值に $0.1^{\circ} \mathrm{C}$ の画像示度上昇が見られた。 また，室内側にカバーガラスが被覆接着されている外表 面（Bゾーン下方）には放射温度画像のかく活が認め られなかった。

写真-13 は, 前述の写真一12 の板ガラス外表面にア セテートフィルム (Bゾーン) とセロファンフィルム

(Cゾーン) で被覆貼付された $25 \mu \mathrm{m} \phi \mathrm{K}$ 型無処理熱電 対を追加したものを，図一5の実験状況に準じて外気側 に配置した放射温度計により日射量約 $412 \mathrm{kcal} / \mathrm{m}^{2} \mathrm{~h} の$ 下で放射温度画像化したものである。繸・横のカーソル 線上の画像示度分布を見ると, カバーガラス上（Aゾー 


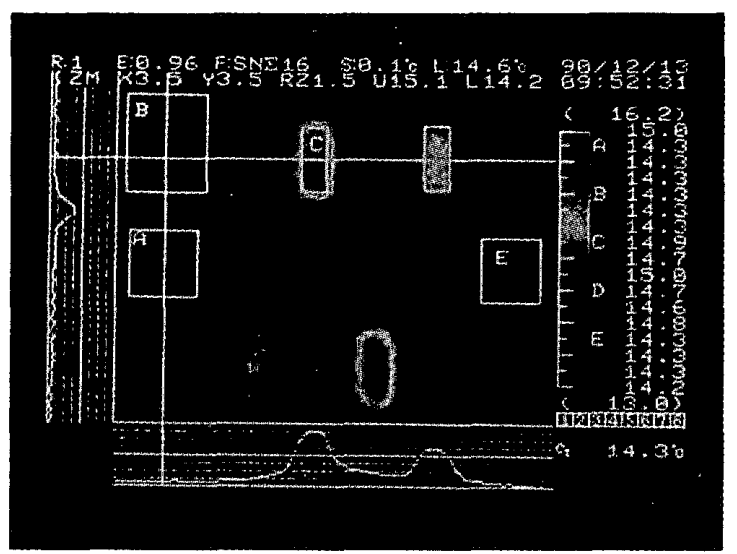

写真一10 室内側各種測温体の放射画像

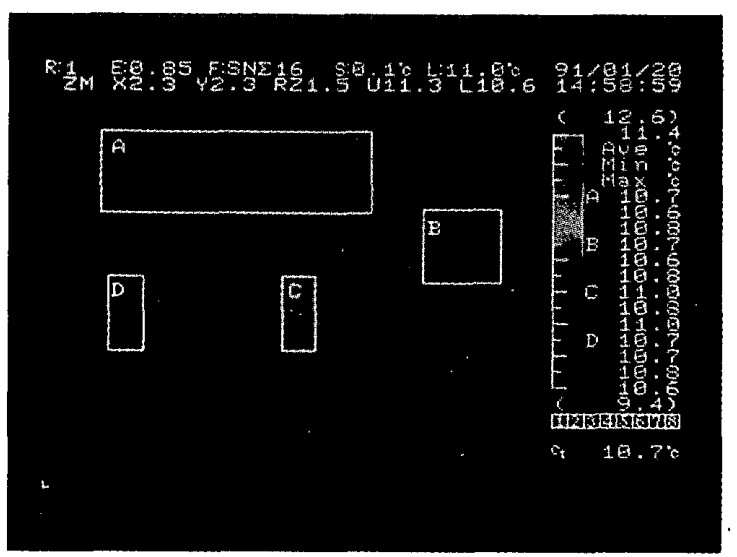

写真一12 外表面側カバーガラス被覆熱電対の放射画像

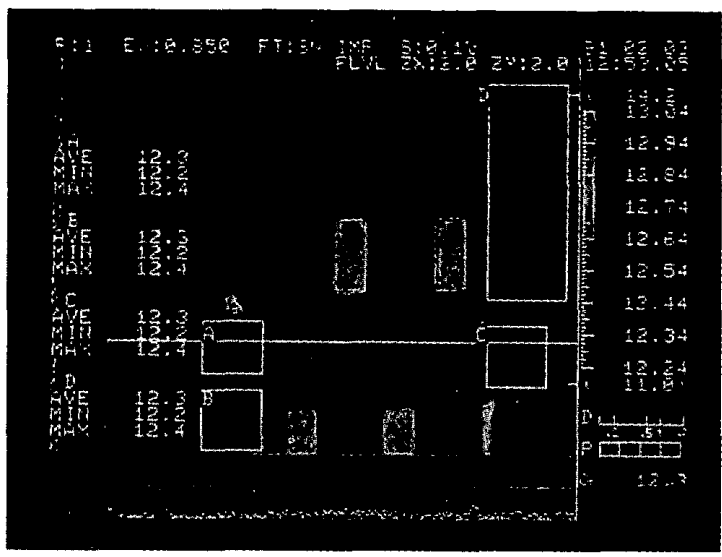

写真一14 外表面側各種測温体の室内側表面への影響

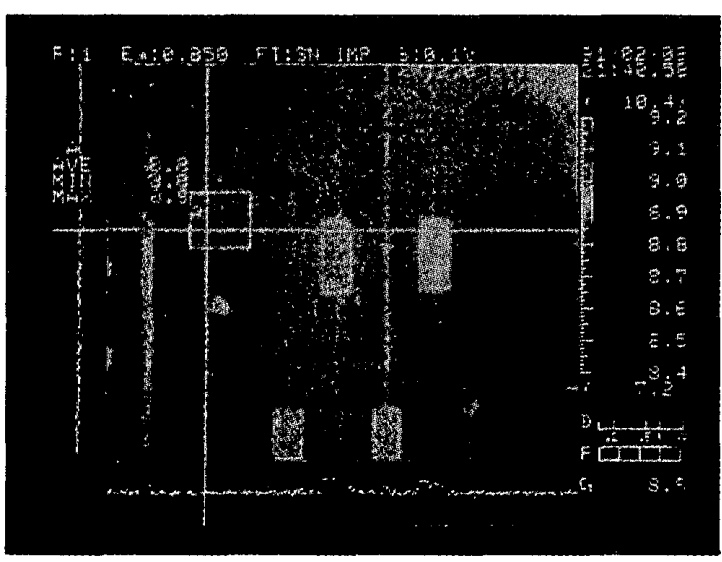

写真一17 液閒，板ガラス外気側に外窓がある埸合
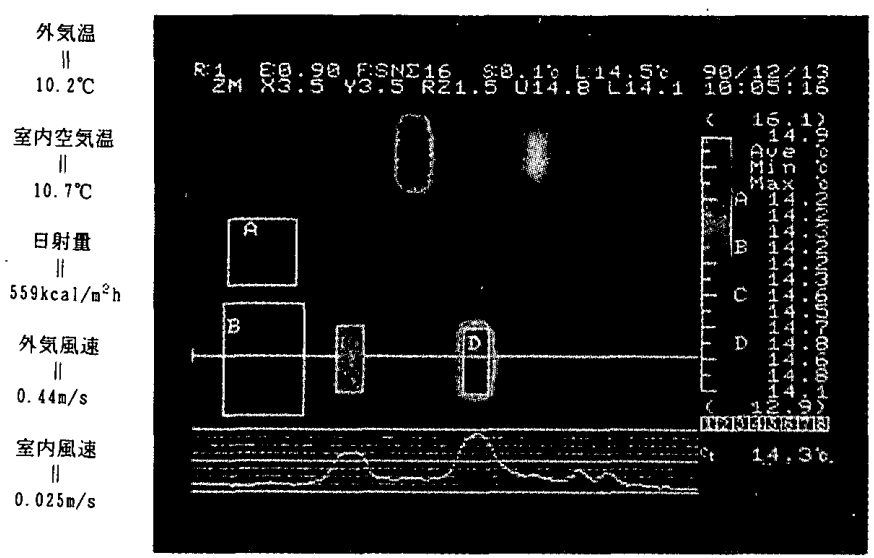

外気温

9. $7^{\circ} \mathrm{C}$

室內空気温

$11.7^{\circ} \mathrm{C}$

日射量

$582 \mathrm{kcal} / \mathrm{m}^{2} \mathrm{~h}$

外気風速

1. $35 \mathrm{~m} / \mathrm{s}$

室内風速

11

$0.07 \mathrm{~m} / \mathrm{s}$

写真一11 室内側各種測温体の放射画像

外気温
$\|$
$13.1^{\circ} \mathrm{C}$
室内空気温
$\|$
$13.2^{\circ} \mathrm{C}$
日射量
$\|$
$380 \mathrm{kcal} / \mathrm{m}^{2} \mathrm{~h}$
外気風速
$\|$
$0.40 \mathrm{~m} / \mathrm{s}$
室内風速
$\|$
$0.04 \mathrm{~m} / \mathrm{s}$

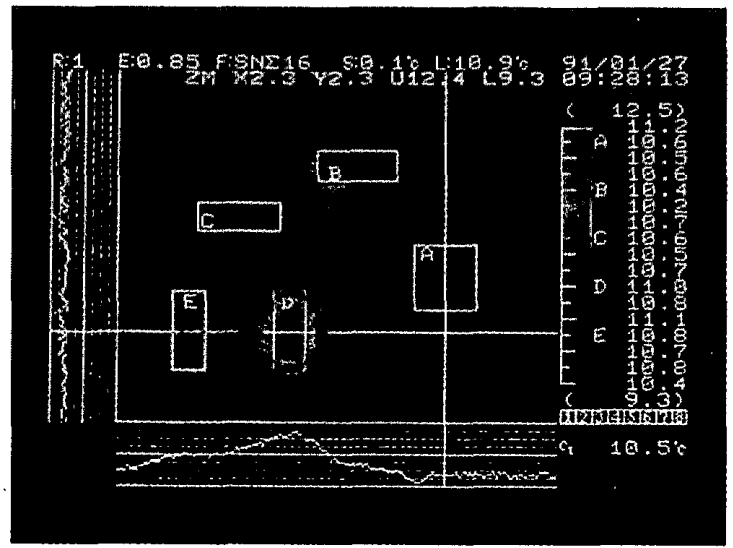

外気温

5. $1^{\circ} \mathrm{C}$

室内空気温

5. $3^{\circ} \mathrm{C}$

日射量

II

$412 \mathrm{kcal} / \mathrm{m}^{2} \mathrm{~h}$

外気風速

II

室内風速

$\|_{0.06 \pi / s}$

写真一13 内・外表面各種測温体の表面温度場への影響

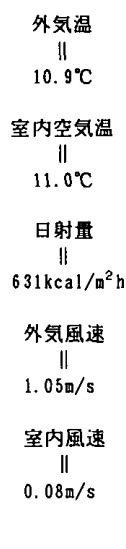

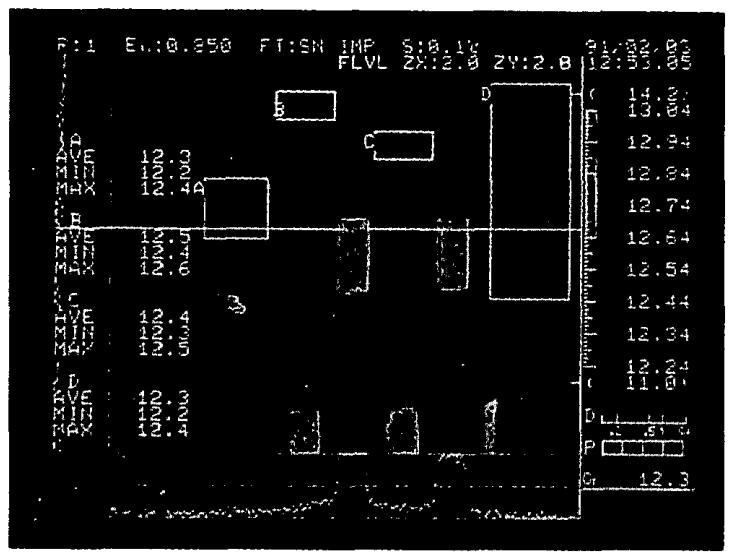

外気温

110. $9^{\circ} \mathrm{C}$

室内空気温

II

$11.0^{\circ} \mathrm{C}$

日射量

II

$631 \mathrm{kcal} / \mathrm{m}^{2} \mathrm{~h}$

外気風速

II

$1.05 \pi / \mathrm{s}$

室内風速

11

写真一15 外表面側各種測温体の室内側表面への影響

外気温
$\|$
$1.9^{\circ} \mathrm{C}$
空内等気温
$\|$
$10.4^{\circ} \mathrm{C}$
日射吾
$\|$
$0 \mathrm{kcal} / \mathrm{m}^{2} \mathrm{~h}$
外気風速
$\|$
$1.79 \mathrm{~m} / \mathrm{s}$
室内風速
$\|$
$0.05 \mathrm{~m} / \mathrm{s}$

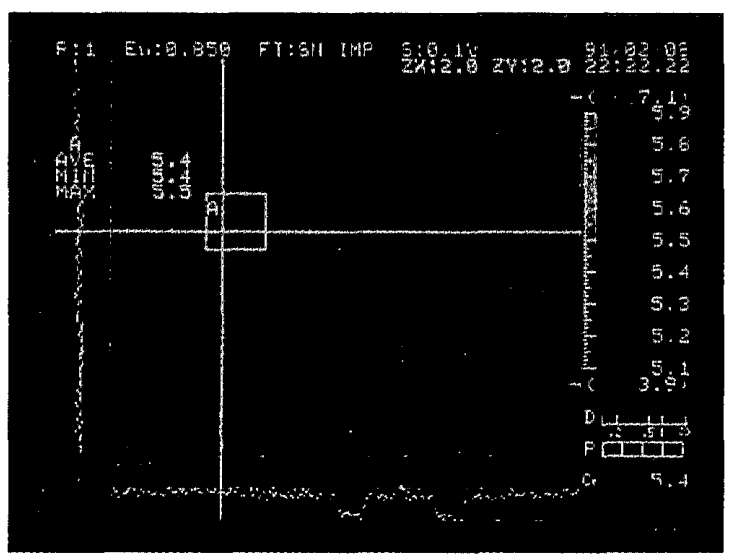

外気温

$0.9^{\circ} \mathrm{C}$

空内空気温

II

9. $9^{\circ} \mathrm{C}$

日射量

akcal/m

外気風速

II

$0.26 \mathrm{~m} / \mathrm{s}$

室内風速

II

$0.10 \mathrm{~m} / \mathrm{s}$

写真一 18 夜間, 板ガラス外裴面が天空に懪される場合 
ン）の画像示度がその周囲の板ガラス上と同様であるの に対し，外表面に追加貼付されたアセテートフィルム被 覆部（Bゾーン）の平均画像示度は $10.4^{\circ} \mathrm{C}$ と, 外表面 カバーガラスの平均画像示度 $\left(10.6^{\circ} \mathrm{C}\right)$ に比べ $0.2^{\circ} \mathrm{C}$ 低いが,このフィルム近傍の板ガラスの放射温度画像は, 表面温度場のかく乱が無いと思われる周囲の板ガラスの 画像より $0.2^{\circ} \mathrm{C} \sim 0.4^{\circ} \mathrm{C}$ 近く画像示度が高く検出されて いる。実際のアセテートフィルム被覆熱電対の測温は $7.2^{\circ} \mathrm{C}$ でありカバーガラス被覆熱電対测温の $6.8^{\circ} \mathrm{C} に$ 比ベ $0.4^{\circ} \mathrm{C}$ 高く, 放射温度画像上のフィルム近傍板ガ ラス表面の温度場かく乱の様態をほぼ裏付けるもので あった。また, セロファンフィルム被覆部（Cゾーン） の放射画像示度の平均值は $10.6{ }^{\circ} \mathrm{C}$ であり, カバーガラ スの平均画像示度と等しいが，実際のその熱電対測温は $7.0^{\circ} \mathrm{C}$ とカバーガラス被覆熱電対测温 $\left(6.8^{\circ} \mathrm{C}\right)$ より $0.2^{\circ} \mathrm{C}$ 高いものであった。この時の視野内背景面の熱電 対測温は $8.7^{\circ} \mathrm{C}$ である。

一方，板ガラスの室内側表面にアセテートフィルム被 覆熱電対が貼付されている外表面部分 (Dゾーン)では, 周囲の板ガラスに対しピーク部分で $0.5 \sim 0.6^{\circ} \mathrm{C}$ 画像示 度が高く，室内側にセロファンフィルム被覆熱電対が貼 付されている外表面部分（Eゾーン）では同 0.2 $0.3^{\circ} \mathrm{C}$ 高くなっている。ゾーン全体の平均值で見ると, 山形のピークを持つ画像示度分布がそのゾーンの中で平 準化されるため，やや低めの示度值となる。ただし， $\mathrm{A}, \mathrm{D}, \mathrm{E}$ の各ゾーンの外表面は放射温度計の測定波長 域について実質的に同一の放射率であるため，前述の画 像示度分布の様態は現実の表面温度分布の様態をかなり 反映していると思われる。これらのゾーンに対忘する室 内側各熱電対測温はカバーガラス被覆が $6.8^{\circ} \mathrm{C}$, アセ

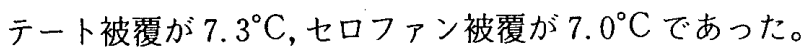
また，室内側にカバーガラス被覆熱電対が装着されてい る外表面部分 (Aゾーン下方) には，放射温度画像の かく乱が認められなかった。

写真一 14,15 は, 前述の写真一13 の板ガラスを室内 側より図一7に示す実験状況にて日射量約 $631 \mathrm{kcal} / \mathrm{m}^{2} \mathrm{~h}$ の下で放射温度画像化したものである。この二枚の写真 も放射温度画像情報としては同一の一画像であり，板ガ ラスの室内側表面に装着されている測温体の種類と配置

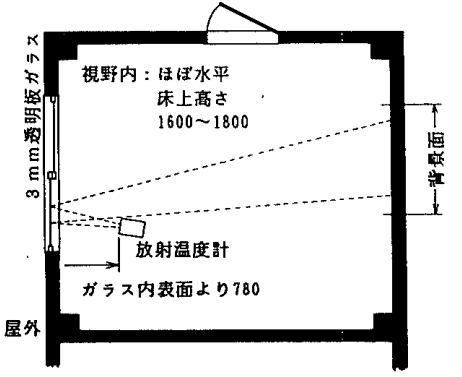

図一7 室内側・近接による検証実験状況概要
は，写真-8 11 と全く同一のものである。

写真一14のAゾーンは室内側に装着されたカバーガ ラス被覆熱電対 ( $12 \mu \mathrm{m} \phi \mathrm{K}$ 型無処理) であり，写真一 8, 10, 11 中のA ゾーンと同一のものである。写真一14 の各ゾーンの画像示度三指標においても, カバーガラス 表面とその周囲の板ガラス表面との間には放射温度画像 上の差異は認められない。カーソル線上の画像示度分布 を見ても同様のことが確認できる。この時のカバーガラ

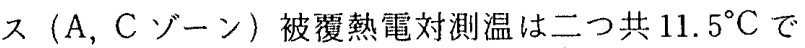
あった。

この写真一14においてむしろ特徴的なことは，室内 側透明テープ貼付位置の上方に，周囲の板ガラスより高 い示度の部分が $2 つ$ 認められることである。この部分を ゾーン設定したものが写真一 15 の B，Cゾーンであり， 各々写真一13 における外表面側の B(アセテートフィル ム被覆)，C（セロファンフィルム被覆）ゾーンの襄側に 対応する。写真一 15 の B ゾーン平均画像示度は

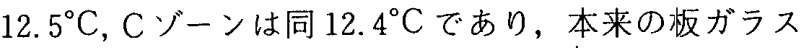
表面 (写真一 14,15 の D ゾーン, 写真-14 の Bゾーン) の平均画像示度 $12.3^{\circ} \mathrm{C}$ に対し, 各々 $0.2^{\circ} \mathrm{C}, 0.1^{\circ} \mathrm{C}$ 上 昇している。これらのゾーン設定範井はいずれも本来の 板ガラス表面であるので, 各ゾーンの平均画像示度の相 対関係は現実の表面温度関係をほぼ反映したものと推察 される。ちなみにここの時の外気側表面のアセテートフィ

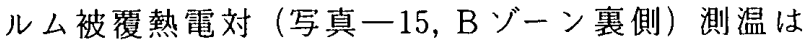
$11.8^{\circ} \mathrm{C}$ ，外気側セロファンフィルム被覆熱電対 (同, $\mathrm{C}$ ゾーン裏側) 測温は $11.6^{\circ} \mathrm{C}$ であり, 外気側表面のカバー

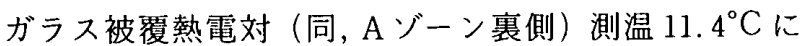
対し, 各々 $0.4^{\circ} \mathrm{C}, 0.2^{\circ} \mathrm{C}$ 测温が高い。

これらに対し，写真一15のAゾーンの室外側表面に はカバーガラス被覆熱電対（写真一 $13, \mathrm{~A}$ ゾーン）が被 覆接着されているが, この部分の室内側表面は,設定ゾ一 ンの画像示度三指標でみても，カーソル線上の画像示度 分布でみても，周囲の板ガラス表面と放射温度画像上の 差異が認められなかった。参考までに，この時の透明板 ガラスに装着されている各種測温体の様子を通常の一眼 レフカメラで室内側より撮影した外観を写真-16に示

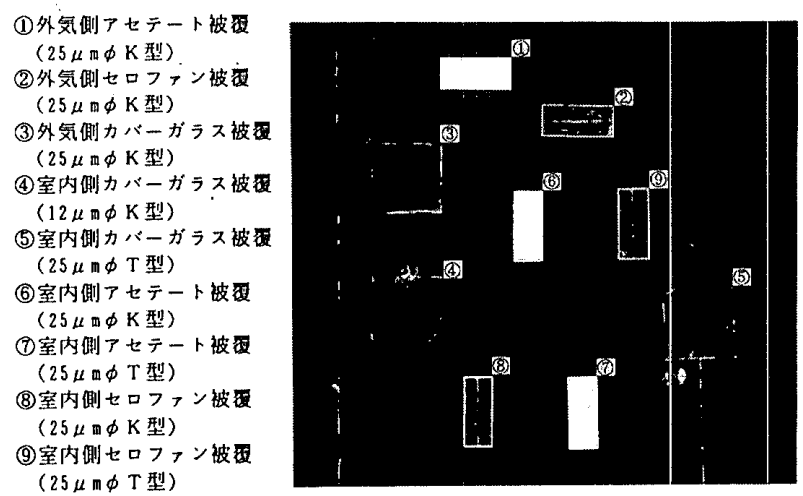

写真一16 各種測温体の窒内側から見た目視外観 
す。

写真一 17,18 は, 板ガラス両表面の測温体の種類・配 置と放射温度計の配置等が写真一14, 15 の場合と全く同 一で，日射の無い夜間に室内側より放射温度画像化した ものである。ただし，写真一17 の場合（時刻，21：40） には，測定対象板ガラスの外気側に中空層を確保するよ うな形で，ポリスチレンフォーム製の枠にはめ込んだ透 明板ガラス (厚 $3 \mathrm{~mm}$ ) を同日夜 $18: 40$ 頃より配置し ていた。この板ガラスを $22: 08$ 頃に取り外し, 测定対 象板ガラス室内側表面の放射温度画像を，その様態が安 定するのを待ってから収録したものが写真一18 (時刻, $22: 22)$ である。両方の放射温度画像の样態や縦・横の カーソル線上の画像示度分布より, この場合でもカバー ガラス表面と周囲の板ガラス表面との間に放射温度画像 上の違いが無いことが分かる。

一方, 写真一17では, 無色透明テープや接着剤の画 像示度が周囲のガラスより相対的に高いのに対し，写真 一18では，これが逆に低くなっているのが目を引く。 ここで，カバーガラス被覆熱電対の測温を見てみると， 写真一 17 の場合が 2 つ共 $7.9^{\circ} \mathrm{C}$ (透明テープ被覆熱電 対も 4 つ共 $7.9^{\circ} \mathrm{C}$ ), 写真一 18 の場合にも 2 つ共 $3.4^{\circ} \mathrm{C}$ (アセテート被覆 $\mathrm{T}$ 型は $3.3^{\circ} \mathrm{C}$, 他の透明テープ被覆熱 電対は $\left.3.4^{\circ} \mathrm{C}\right)$ となり，板ガラスの温度が外気や天空等 に曝されて低下していることが確認できるが，この間放 射温度計視野内背景面の熱電対測温は $6.6^{\circ} \mathrm{C}$ か $6.4^{\circ} \mathrm{C}$ へと比較的わずかな変化にとどまっており, その 結果, 室内側のカバーガラス被覆熱電対測温と背景面測 温との相対的な温度関係は, 写真一 17 では各々 $7.9^{\circ} \mathrm{C}$ と6. $6^{\circ} \mathrm{C}$ であるのに対し, 写真一 18 では $3.4^{\circ} \mathrm{C} と$ $6.4^{\circ} \mathrm{C}$ と逆転している。

これらのことより, 背景面測温よりカバーガラス被覆 熱電対測温が高い場合には，本論文で用いた無色透明 テープや接着剤なよ゙は，その周囲の板ガラスより放射温 度画像示度が相対的に高く表示され，背景面測温よりカ バーガラス被覆熱電対測温が低い場合には，無色透明 テープや接着剤は周囲の板ガラスより画像示度が低く表 示されると，ここでは見ることができそうである。この ことは, 写真一13の外表面側の各透明テープとその近 傍の板ガラスとの間の画像示度関係や，写真一 12,13 の 外表面側力バーガラスの外縁および下方の接着剤と周囲 の板ガラスとの間の画像示度関係等にも共通して認めら れる。

さらに写真一18で興味深いのは，外気側表面に装着 された透明テープ等の影響が，夜間においても板ガラス の室内側表面における温度場のかく乱として認められる ことである。これらに対し，外表面側にカバーガラスが 被覆接着されている部分の室内側表面（写真一17, 18 の Aゾーン)の放射温度画像はその周囲と同じ様態であり,
夜間においても裏側表面の温度場のがく乱は認められな かった。写真一18の外気側カバーガラス被覆測温は $3.1^{\circ} \mathrm{C}$, 同アセテート被覆は $2.9^{\circ} \mathrm{C}$, 同セロファン被覆 は $3.0^{\circ} \mathrm{C}$ であった。

\section{6. 本論文のガラス表面温度用測温体の測定精度の吟味}

前章 5. で報告してきたように，予想される代表的な 種々の状況下で, 本論文の測温体の表面であるカバーガ ラスと測定対象ガラスとの間には，日射量 $600 \mathrm{kcal} /$ $\mathrm{m}^{2} \mathrm{~h}$ 前後の下, 放射温度計の最小検知温度差が約 0.025 ${ }^{\circ} \mathrm{C}$ の水準の時でもその放射温度画像上に差が認められ なかった。

ここで, 測温体の感温素子である熱電対の感温接点部 の温度を感温層の厚さ方向において一つの温度と見なす と, 熱電対感温接点の温度と測温体周囲の測定対象ガラ ス表面温度との間に前述の最小検知温度差以上の違いが あるとすれば，この違いの主な部分は，感温接点および 接着肪を被覆しているカバーガラスの両側表面の温度差 によるものであると考えられる。そこで本章では，提案 した測温体によるガラス表面温度測定で精度追求上厳し いと思われる状況を想定し，測温体の熱的構造などから その熱挙動の概略を推察し, 本研究で講じた検証実験の 範囲でじの程度の確からしさまで言及することができる のか検討してみることとした。ただし，ここでは熱電対 自体の感温素子としての精度や，その熱起電力の大・小 と電圧計測側の分解能・精度に起因する問題等とは一応 切り離して考えることとする。

カバーガラスの両側表面に温度差が生じる主な状況と しては，熱電対および接着剤の日射等の短波長放射吸収 が大きく感温層の温度が真の表面温度よりも高くなる か、熱電対による反射日射の吸収により入射側ガラス部 の温度が高くなるかにより，カバーガラスの厚さ方向に 局所熱流が生じる場合と，板ガラスを境にその両側の空 気温度の差が大きく, 相当量の貫流熱流がカバーガラス も含めた板ガラスの厚さ方向に生じる場合とが考えられ る。

前者の場合, 日射が板ガラス内に入射した後, 多重反 射などのプロセスも経て感温層に入射する時の強さは大 きくとも $600 \mathrm{kcal} / \mathrm{m}^{2} \mathrm{~h}$ 程度と見積れば十分ではないか と考えられる。感温層の日射吸収率を仮に $40 \%$ と相当 大きく見積り，これにより吸収された熱が，相対的に熱 抵抗の小さいカバーガラス側に定常熱流ですべて流れた と仮定しても，この熱流束に対応するカバーガラス両側 表面の温度差は約 $0.023^{\circ} \mathrm{C}$ 程度礼稚察される。また， 熱電対による反射日射の吸収による入射側ガラス部の温 度上昇によりカバーガラスに生じる熱流束も前述の想定 より大きくなるとは考えにくい。

次に板ガラスの内・外空気温度差により相当量の貫流 
熱流が生じる場合を考える。熱貫流率 $5.8 \mathrm{kcal} / \mathrm{m}^{2} \mathrm{~h}^{\circ} \mathrm{C}$ 前後とされる正味厚 $3 \mathrm{~mm}$ の透明板ガラスで構成される 空の屋外気温が $-15^{\circ} \mathrm{C}$, 屋内気温が $+25^{\circ} \mathrm{C}$ と仮定する と貫流熱流束は約 $232 \mathrm{kcal} / \mathrm{m}^{2} \mathrm{~h}$ 程度となり, 正味厚 3 $\mathrm{mm}$ の板ガラスの両側表面温度差は約 $1.05^{\circ} \mathrm{C}$ 程度であ ると考えられる。測温体の熱抵抗がカバーガラス表面温 度に及ぼす影響を考えるに当り, 感温層の熱伝導特性と して熱伝導率の小さい接着剤のほうを採り，その值とし て物性の近いアクリル樹脂の約 $0.18 \mathrm{kcal} / \mathrm{mh}^{\circ} \mathrm{C}$ を仮定 すると, 感温層は熱伝導係数上その厚さの約 3.6 倍のガ ラスに置き換えることができる。仮に感温層の実際の厚 さを $40 \mu \mathrm{m}$ 前後 ${ }^{ \pm 6)}$ とすれば，カバーガラスと合わせて 測温体の測定対象ガラス表面への装着で約 $200 \mu \mathrm{m}$ ガラ スの厚さが増加したと見ることができる。概略的な仮定 の話であるが，測温体の有・無による見掛けの板厚（熱 抵抗)変化の影響が局所的な熱流束の違いの形で現れず, 一様な熱流束の仮定の下，すべてカバーガラスの表面温 度の変化に現れたとすると，それは厚 $3 \mathrm{~mm}$ 板ガラスの 場合, 内・外気温差 $40^{\circ} \mathrm{C}$ の設定で約 $0.029^{\circ} \mathrm{C}$, 同 $20^{\circ} \mathrm{C}$ 差の設定の下では約 $0.014^{\circ} \mathrm{C}$ となり, 通常の測定状況 では大きな問題とはならないと考えられる。

\section{7. まとめ}

（1）接触式表面温度測定方法でありながら，測温体装 着後も測温体表面の放射熱収支特性や対流熱伝達特性が 周囲の透明板ガラスと同様な方法を考案した。これは, 素線径 $25 \mu \mathrm{m} \phi$ 以下の無処理熱電対をシアノアクリレー 卜系無色透明接着剤（低粘性型）を用い，公称厚 50 $75 \mu \mathrm{m}$ のカバーガラス $(30 \mathrm{~mm} \times 30 \mathrm{~mm})$ で被覆接着す るものである。

（2）地上の太陽放射や，天空との対向による放射冷却 等に曝される現実の開口部（空）の透明板ガラスを対象 として, 考案したガラス表面温度用測温体の検証を行つ た。本論文の測温体の表面と，その周囲の透明板ガラス 表面との間には, 日射量 $600 \mathrm{kcal} / \mathrm{m}^{2} \mathrm{~h}$ 前後の下, 放射 温度計の最小検知温度差が $0.025^{\circ} \mathrm{C}$ の水準においても 放射温度画像上の差異は認められなかった。

（3）本論文のカバーガラス被覆熱電対の感温接点温度 とカバーガラス空気側表面との温度差は，感温層等の日 射熱吸収による局所熱流の想定でも（大きくとも $0.023^{\circ} \mathrm{C}$ 程度), 内・外気温差による貫流熱流による想 定でも $\left(40^{\circ} \mathrm{C}\right.$ 差で $0.029^{\circ} \mathrm{C}, 20^{\circ} \mathrm{C}$ 差で $0.014^{\circ} \mathrm{C}$ 差前 後), 極めてわずかと推察された。検証実験中の放射温 度計の最小検知温度差等を勘案すると, 熱電対感温接点 温度と真のガラス表面温度との差は, 測定精度追求上相 当厳しい状況の下でも, $0.1^{\circ} \mathrm{C}$ 以内の水準にあるとして 差し支えないと考えられる。

（4）アセテートフィルムがベース材の通称メンディン $-36-$
グテープで被覆された熱電対（素線径 $25 \mu \mathrm{m} \phi$ 以下，纬 処理）測温は, 本論のカバーガラス被覆熱電対測温に対 し, 日射量 $600 \mathrm{kcal} / \mathrm{m}^{2} \mathrm{~h}$ 前後の下で約 $0.3 \sim 0.5^{\circ} \mathrm{C}$ 高く なり, 夜間に天空に曝される側では, 約 $0.1 \sim 0.2^{\circ} \mathrm{C}$ 低 い測温となった。セロファンフィルムがベース材の通称 セロハンテープで被覆された同熱電対測温は, 本論の力 バーガラス被覆熱電対測温に対し，日射量 600 $\mathrm{kcal} / \mathrm{m}^{2} \mathrm{~h}$ 前後の下で約 $0.2 \sim 0.3^{\circ} \mathrm{C}$ 高く, 夜間に天空に 面する側では, 約 $0.1^{\circ} \mathrm{C}$ 程度低くなっている。これららは, 主に各透明テープと板ガラスとの放射特性の違いによる 表面の放射熱収支の違いが各熱電対測温に現れたものと 考えられる。

（5）板ガラス表面での短・長波長放射のやり取りが相 対的に大きい状況では, 各透明テープ貼付位置の裏側の ガラス (3 mm 厚) 表面にも温度場のかく乱が及んでい た。カバーガラス被覆の場合は, 外気側, 室内側よ゙ちら に装着してもその裏側表面に温度場のかく乱は認められ なかった。

（6）カバーガラス被覆熱電対測温と，比較のために用 意した各測温体測温との差は，検証実験中，おおむ被 覆材の材質と日射量によって支配されていたが, 外気風 速の大・小や長波長放射環境の違い等の影響を受けるこ とも伺えた。このため, 現時点で各種の測定方法との体 系的な比較 (誤差)を論じるにはいまだ測定数が十分で はないと考えられ，この問題については次報に譲ること としたい。

\section{謝 辞}

透明板ガラス（厚 $3 \mathrm{~mm}$ ) および同板ガラスに装着し たカバーガラス表面の分光放射特性の測定に際し，本学 理学部, 化学・応用化学科の小出直之教授の御協力を得 ました。記して謝意を表します。

注

1）一般的にセロハンテープ,メンデングテープレ称されて いる無色透明の各粘着テープについて，その代表的㹈造 メーカーへ問い合わせた結果。

2） K 型熱電対は $\mathrm{T}$ 型に比べ素線の引張強度が高いため, 極 細線径の熱電対を扱う場合にはその分作業が容易となり， 素線径 $12 \mu \mathrm{m} \phi$ のものまで扱える。また耐酸化性にも優 れている。中高温域 $\left(200^{\circ} \mathrm{C} \sim 600^{\circ} \mathrm{C}\right)$ の測定では「短範 囲規則化誤差」と言う問題もあるが，常温域の測定では 熱起電力特性の直線性も安定性も良好である。

3）多くの無色透明接着郕は基材である合成樹脂を溶骫に溶 かしたもので, 比較的粘性の高いものが多く接着層が厚 くなりがちである。低粘性のものもあるが, ガラスとカ バーガラスの間では溶䏡の気化が順調に進まず硬化に非 常に時間を要し, 垂直なガラス面への装着の湯合に㳖， 硬化前に接着凨が垂れ落ち過ぎ，入れ替かりのように気 泡か接着層に入ることも多い。

4）常温の黒体を走查する場合，本研究で用いた湤射温度計 
が検出し得る放射エネルギーの 9 割以上はこの半值幅表 示の測定波長域内で検出されると称されている。

5) カバーガラス厚を公称厚の中央值：約 $63 \mu \mathrm{m}$ と仮定, そ の熱伝導率は通常の透明板ガラスと同程度とした。

6）使用熱電対の感温接点は品質の安定した工場生産品で, 顕微鏡で拡大するとほぼ球形であり，その大きさは素線 径の 1.5 倍 2 倍弱であった。これを押し漬し厚さを薄 くする方法もあるが, 本研究では短波長放射の影響と成 形サイズのばらつきを眊念し押し潰さずに使用した。

\section{参考文献}

1）宮野秋彦，小林定教：熱電対による表面温度测定につい $\tau$, 日本建築学会論文報告集, No. 253, pp. $81 \sim 89$, 1977.3

2）梅干野晃，塩月義隆，林宏幸：日射透過材料の表面温 度测定法に関する実験研究, 日本建築学会大会学術講演 梗概集，pp.699 700，1984.10

3）梅干野晃，塩月義隆，林宏幸，川野洋一：日射透過材 料の表面温度測定法に関する実験研究（その2)，日本建 築学会大会学術講演梗概集，pp. 831～832，1985.10

4）梅干野晃，塩月義隆，林宏幸：日射透過材料の表面温 度测定法に関する実験研究（その 3 ），日本建築学会大会 学術講演梗概集, pp. 833 834, 1985.10

5）梅干野晃，塩月戔隆，林宏幸：日射透過材料の表面温 度測定法に関する実験的研究，日本建築学会計画系論文 報告集，No. 408，pp.13－21，1990.2

6）梅干野晃, 川合博英, 笠井 豊：赤外線放射カメラ $(6.5$
〜8.6 $\mu \mathrm{m}$ ) を用いたガラスの表面温度測定（多重分光赤 外画像による建築熱環境の計測・その 2 ), 日本建築学会 大会学術講演梗概集, pp. $465 \sim 466,1988.10$

7）筆者ら：開口部の熱流に関する研究（空部位の熱流測定 装置における各種センサーの開発・その 1$)$, 日本建築学 会大会学術講演梗概集, pp. 839 - 840, 1987.10

8）筆者ら：開口部の熱流测定装置の開発（空気温度測定方 法とガラス温度測定方法の検討・その 1$)$, 空気調和・衛 生工学会学術講演会講演論文集, pp. $625 ６ 28,1987.10$

9）筆者ら：開口部の熱流測定装置の開発（空ガラス温度の 测定方法之実験結果の検討・その 3$)$, 空気調和・衛生工 学会学術講演会講演論文集, pp. 369 - 372, 1988.9

10）筆者ら：開口部の熱流に関する研究（開口部熱流測定装 置の検討・その 4 ), 日本建築学会大会学術講演梗概集, pp. 845 846, 1989.10

11）筆者ら：開口部熱流測定装置の開発（短波長放射環境下 における窓ガラス温度测定方法に関する実験的研究・そ の 4 ), 空気調和・衛生工学会学術講演会講演論文集, pp. 453 456, 1989.10

12）JIS A 1422-1982 日除けの日射遮蔽係数簡易試験方法

13）木村健一：建築設備基礎理論演習, 学献社 1970 年, 7 版 (1984) pp. 94

14）筆者ら：短波長放射のある室内における空気温度測定方 法に関する実験的研究, 日本建築学会計画系論文報告集, No. 399 , pp. $1 \sim 10,1989.5$

(1991 年 4 月 2 日原稿受理, 1991 年 6 月 14 日採用決定) 